\title{
MANAJEMEN KURIKULUM \\ DALAM UPAYA PENINGKATAN MUTU PENDIDIKAN
}

\author{
Yuhasnil $^{1}$, Silvia Anggreni \\ STKIP Yayasan Abdi Pendidikan Payakumbuh ${ }^{1,2}$ \\ yuhasnil.yy@ gmail.com ${ }^{1}$
}

\begin{abstract}
ABSTRAK
Tujuan penelitian untuk menelaah manajemen kurikulum dalam upaya peningkatan mutu pendidikan. Metode yang digunakan adalah studi pustaka. Dengan tujuan untuk melihat manajemen kurikulum dalam meningkatkan mutu pendidikan melalui peningkatan mutu dan kualitas sumber daya manusia. Usaha untuk meningkatkan mutu pendidikan harus didukung oleh semua pihak, termasuk para pengelola lembaga pendidikan di tingkat pusat, wilayah sampai pada tingkat sekolah termasuk di kelas. Pelaksanaan desentralisasi pendidikan di era otonomi daerah, masing-masing daerah seyogianya memiliki rancangan kurikulum peningkatan mutu tersendiri yang merupakan penjabaran atau implementasi dari kurikulum pendidikan yang ditetapkan oleh pusat. Hal demikian sangat sesuai dengan tuntutan kurikulum, dimana baik pemerintah daerah maupun pada level bawah sekalipun (sekolah) diberikan kebebasan untuk menjabarkan programprogram peningkatan mutu sehingga dikemudian hari dimasing-masing daerah saling berkompetisi demi kemajuan pendidikan di daerah masing-masing.
\end{abstract}

Kata Kunci : Manajemen Kurikulum, Mutu Pendidikan, Sumber Daya Manusia

\begin{abstract}
The research objective is to examine curriculum management in an effort to improve the quality of education. The method used is literature study. With the aim of seeing curriculum management in improving the quality of education through improving the quality of human resources. Efforts to improve the quality of education must be supported by all parties, including managers of educational institutions at the central, regional and school levels including in the classroom. In the implementation of decentralized education in the era of regional autonomy, each region should have its own quality improvement curriculum design which is an elaboration or implementation of the education curriculum set by the center. This is in accordance with the demands of the curriculum, where both local governments and even lower levels (schools) are given the freedom to describe quality improvement programs so that in the future each region competes with each other for the advancement of education in their respective regions.
\end{abstract}

Keywords: Curriculum Management, Education Quality, Human Resources 


\section{PENDAHULUAN}

Undang-undang Nomor. 20 Tahun 2003 tentang Sistem Pendidikan Nasional menjelaskan bahwa pemerintah dalam penyelenggaraan pendidikan mampu menjamin pemerataan kesempatan pendidikan, peningkatan mutu serta relevansi dan efisiensi manajemen pendidikan. Dalam penjelasan undang-undang Sisdiknas ditetapkan pembaharuan visi, misi dan strategi pembangunan pendidikan nasional. Pembaharuan pendidikan tersebut diperlukan perubahanperubahan di antaranya dalam hak dan kewajiban warga Negara, orang tua, masyarakat, dan pemerintah; standar penilaian nasional, kurikulum berdiversifikasi, pendidik dan tenaga kependidikan, sarana dan prasarana pendidikan, pendanaan, pengelolaan pendidikan, peran serta masyarakat, evaluasi, akreditasi dan sertifikasi dan pendirian satuan pendidikan. Hubungan di antara bidang-bidang pembaharuan tersebut dikelola secara terpadu untuk mencapai tujuan pendidikan nasional.

Kualitas SDM Indonesia belum sesuai dengan harapan nasional, bahkan cenderung menurun, apalagi memenuhi standar internasional. SDM yang merupakan produk dari suatu lembaga pendidikan atau pelatihan sangat menentukan perkembangan tatanan ekonomi, hukum, politik, dan sosial masyarakat. Selain itu keberhasilan dalam menghadapi persaingan global juga ditentukan oleh kemampuan SDM, yang memiliki kemampuan unggul akan berhasil sedangkan yang tidak unggul akan tersisih dari persaingan. Persaingan yang terjadi adalah persaingan kemampuan atau kompetensi lulusan lembaga pendidikan. Mutu pendidikan kita harus bisa mendorong semua sekolah agar benar-benar ikut berusaha untuk meningkatkan mutu pendidikan. Usaha untuk meningkatkan mutu pendidikan harus didukung oleh semua pihak, termasuk para pengelola lembaga pendidikan di tingkat pusat, wilayah sampai pada tingkat sekolah termasuk di kelas (Semiawan, 2002)

Menurut Agustiani (2017) banyaknya fenomena lemahnya mutu sebagian lembaga pendidikan di Indonesia dengan ditandai berbagai problematika seperti masih rendahnya manajemen sekolah. Lembaga pendidikan memerlukan manajemen yang mempunyai tipe perencanaan yang tidak sekadar untuk merespon perubahan yang diperkirakan akan terjadi di masa depan, namun lebih dari itu. Lembaga pendidikan memerlukan manajemen yang mempunyai tipe perencanaan untuk menciptakan masa depan lembaga pendidikan melalui perubahan-perubahan yang dilaksanakan sejak sekarang. Dalam manajemen tradisional, manajemen kurikulum merupakan tanggung jawab manajemen puncak, yang memberikan pengaruh besar terhadap mutu lembaga pendidikan. Artikel ini menitik beratkan kepada manajemen mutu pendidikan dari segi Sumber Daya Manusianya, selain dari manajemen lembaga pendidikan.

Mutu pendidikan tidak akan memuaskan apabila komponen-komponen pendidikan yang meliputi landasan, tujuan, kurikulum, kompetensi dan profesionalisme guru, pola hubungan guru murid, metodologi pembelajaran 
sarana prasarana, evaluasi, pembiayaan dan unsur lainnya dikelola apa adanya tanpa perencanaan yang matang. Sedangkan Untuk mencapai suatu pendidikan yang baik dan berkualitas maka perlu adanya sebuah manajemen yang baik terutama dalam bidang kurikulum yang akan diajarkan kepada anak didik baik mengenai tujuan, isi atau bahan ajar, pelaksanaan serta evaluasi dari kurikulum. Dengan menerapkan manajemen kurikulum secara profesional lembaga pendidikan pendidikan tersebut akan menghasilkan lulusan yang bermutu yang mampu membentuk lulusannya agar memiliki kecakapan hidup. Artikel di atas melihat manajemen kurikulum dalam meningkatkan mutu pendidikan di lihat dari proses belajar mengajar, sementara artikel ini melihat manajemen kurikulum dapat meningkatkan mutu pendidikan dilihat dari segi peningkatan kualitas Sumber Daya manusia.

Wahyuni, (2009) banyaknya fenomena lemahnya mutu sebagian lembaga pendidikan di Indonesia dengan ditandai berbagai problematika seperti masih rendahnya manajemen sekolah. Lembaga pendidikan memerlukan manajemen yang mempunyai tipe perencanaan yang tidak sekadar untuk merespon perubahan yang diperkirakan akan terjadi di masa depan, namun lebih dari itu. Lembaga pendidikan memerlukan manajemen yang mempunyai tipe perencanaan untuk menciptakan masa depan lembaga pendidikan melalui perubahan-perubahan yang dilaksanakan sejak sekarang. Dalam manajemen tradisional, manajemen kurikulum merupakan tanggung jawab manajemen puncak, yang memberikan pengaruh besar terhadap mutu lembaga pendidikan. Artikel di atas membahas manajemen kurikulum dalam meningkatkan mutu pembelajaran dilihat dari proses belajar mengajar, sedangkan artikel ini membahas manajemen kurikulum dalam meningkatkan mutu pendidikan dengan meningkatkan kualitas sumber daya manusia. Menciptakan pendidikan yang berkualitas maka diperlukan manajemen dalam bidang kurikulum yang ingin di ajarkan terhadap siswa baik tentang tujuan, bahan ajar, proses pelaksanaannya dan evaluasi kurikulum. Mmanajemen kurikulum dalam proses pembelajaran atau melihat manajemen pembelajaran. Artikel ini melihat manajemen kurikulum dalam meningkatkan mutu dan kualitas sumber daya manusia.

\section{METODE PENELITIAN}

Penelitian ini adalah penelitian kualitatif yang bersifat studi pustaka (library research) yang menggunkan buku-buku dan literatur-literatur lainnya sebagai objek yang utama. Jenis penelitian yang digunakan adalah kualitatif, yaitu penelitian yang menghasilkan informasi berupa catatan dan data deskriptif yang terdapat di dalam teks yang diteliti. Dengan penelitian kualitatif, perlu dilakukan analisis deskriptif. Metode analisis deskriptif memberikan gambaran dan keterangan yang secara jelas, objektif, sistematis, analitis dan kritis mengenai Manajemen Kurikulum dalam Upaya Peningkatan Mutu Pendidikan. Pendekatan kualitatif yang didasarkan pada langkah awal yang ditempuh dengan 
mengumpulkan data-data yang dibutuhkan, kemudian dilakukan klasifikasi dan deskripsi.

Sebagai penelitian kepustakaan, maka sumber data ada dua macam yang akan dipaparkan sebagai berikut:

1. Sumber primer adalah suatu referensi yang dijadikan sumber utama acuan penelitian. Dalam penelitian ini, sumber primer yang digunakan adalah buku dari Depdiknas, Pengendalian Mutu Pendidikan dan Dasar-dasar Pengembangan Kurikulum.

2. Sumber sekunder adalah referensi-referensi pendukung dan pelengkap bagi sumber primer.

Dalam penelitian kepustakaan, metode yang digunakan untuk mengumpulkan data penelitian berupa data-data kepustakaan yang telah dipilih, dicari, disajikan dan dianalisis. Studi pustaka di sini adalah studi pustaka tanpa disertai uji empirik. Data yang disajikan adalah data yang berbentuk kata yang memerlukan pengolahan supaya ringkas dan sistematis. Dengan prosedur sebagai berikut :

1. Pengumpulan data yang dilakukan dalam penelitian ini adalah dengan mengumpulkan buku-buku tentang nilai, pendidikan.

2. Kemudian dipilih, disajikan dan dianalisis serta diolah supaya ringkas dan sistematis.

3. Analisis adalah serangkaian upaya sederhana tentang bagaimana data penelitian pada gilirannya dikembangkan dan diolah ke dalam kerangka kerja sederhana. Data yang sudah terkumpul kemudian dianalisis untuk mendapatkan informasi, namun terlebih dahulu data tersebut diseleksi atas dasar reliabilitasnya .

4. Setelah keseluruhan data terkumpul maka langkah selanjutnya penulis menganalisa data tersebut sehingga ditarik suatu kesimpulan.Untuk memperoleh hasil yang benar dan tepat dalam menganalisa data, penulis menggunakan teknik analisis isi. Analisis isi (Content Analysis) adalah penelitian yang bersifat pembahasan mendalam terhadap isi suatu informasi tertulis atau tercetak di media massa. Analisis isi dapat digunakan untuk menganalisa semua bentuk komunikasi, baik surat kabar, berita radio, iklan televisi maupun semua bahan dokumentasi yang lainnya9. Sedangkan kaitannya dengan pembahasan yaitu sebagai salah satu upaya penulis dalam memudahkan pemahaman dengan cara menganalisa kebenarannya .

Adapun langkah- langkah strategis dalam penelitian analisis isi, sebagai berikut :

1. Penetapan desain atau model penelitian. Disini ditetapkan beberapa media, analisis perbandingan atau korelasi, objeknya banyak atau sedikit dan sebagainnya. 
2. Pencarian data pokok atau data primer, yaitu teks sendiri. Sebagai analisis isi, teks merupakan objek yang pokok, bahkan terpokok. Pencarian dapat dilakukan dengan menggunakan lembar formulir pengamatan tertentu yang sengaja dibuat untuk keperluan pencarian data tersebut.

3. Pencarian pengetahuan konstektual agar penelitian yang dilakukan tidak berada diruang hampa, tetapi terlihat kait-mengait dengan faktor-faktor lain.

\section{HASIL PENELITIAN}

Manajemen sebagai suatu proses yang nyata mulai dari perencanaan, pengorganisasian, penggerakan dan pengendalian yang dilakukan untuk menentukan dan menyelesaikan sasaran yang telah ditetapkan dengan menggunakan orang dan sumber-sumber daya lainnya. Manajemen pendidikan merupakan bentuk kerja sama personil pendidikan untk mencapai tujuan pendidikan itu. Tujuan umum yang akan dicapai dalam kerjasama itu adalah pembentukan kepribadian murid sesuai dengan tujuan pendidikan nasional dan tingkat perkembangannya pada usia pendidikan. Tujuan ini dapat dijabarkan ke dalam tujuan kurikuler, tujuan instruksional umum, dan tujuan istruksional khusus. Manajemen pendidikan juga merupakan suatu proses yang merupakan (siklus) penyelengaraan pendidikan dimulai dari perencanaan, pelaksanaan, pemantauan dan evaluasi tentang usaha sekolah untuk mencapai tujuannya. Manajemen pendidikan merupakan usaha pengelolaan system pendidikan dan juga merupakan kegiatan mengambil keputusan serta berkomunikasi dalam organisasi sekolah sebagai usaha unutk mencapai tujuan pendidikan.

Kegiatan manajemen pendidikan atau manajemen sekolah mencakup beberapa komponen yang saling terkait, yaitu; 1) manajemen kurikulum dan program pengajaran, 2) tenaga kependidikan, 3) kesiswaan, 4) keuangan dan pembiayaan, 5) sarana dan prasarana pendidikan, 6) hubungan sekolah dengan masyarakat, 7) layanan khusus

Berkaitan dengan manajemen kurikulum, makna dan definisi kurikulum itu sering ditafsirkan secara berbeda-beda dikalangan para ahli. Secara harfiah kurikulum berasal dari bahasa latin (corre) yang berarti lapangan pertandingan. Dengan pengertian ini maka kurikulum berarti arena pertandingan tempat para pelajar bertanding untuk menguasai suatu pelajaran guna mencapai garis garis finish berupa ijazah atau gelar kesarjanaan. Dalam pengertian sehari-hari kurikulum mengandung arti sebagai seperangkat mata pelajaran yang harus dipelajari oleh siswa di sekolah atau lembaga pendidikan. Berdasarkan pengertian itu seperangkat mata pelajaran tersebut memberikan informasi yang tidak utuh mengenai isi dan proses pemahaman bahan-bahan mata pelajaran yang bersangkutan.

Manajemen kurikulum dititikberatkan dalam dentuk kegiatan yang berhubungan dengan tugas guru serta kegiatan yang berhubungan dengan proses pelaksanaan belajar mengajar. Kegiatan yang berhubungan dengan tuugas guru 
meliputi pembagian tugas mengajar, pembagian tugas/tanggung jawab dalam membina ekstra kurikuler, dan koordinasi penyusunan persiapan mengajar. Sementara kegiatan yang berhubungan dengan proses pelaksanaan belajar mengajar terdiri atas: 1) penyusunan jadwal pelajaran, 2) penyusunan program (rencana) berdasarkan satuan waktu tertentu (seperti catur wulan, semester, atau tahunan), 3) pengisian daftar kemajuan murid, 4) penyelenggaraan evaluasi hasil belajar, 5) laporan hasil evaluasi ,dan, 6) kegiatan bimbingan penyuluhan.

Pengendalian mutu pendidikan (educational quality control) pada hakekatnya adalah pengendalian SDM yang membutuhkan informasi atau data tentang keadaan sekolah agar program yang direncanakan sekolah lebih tepat sasaran terhadap pencapaian hasil belajar siswa yang optimal. Apabila sekolah yang efektif (school effectiveness) mampu menjalankan program-programnya, maka ia akan mampu menghasilkan profil lulusan yang berprestasi maksimal. Namun, satunya adalah frekuensi penggunaan penilaian oleh guru dan kepala sekolah dalam menemukan data atau informasi sebagai bahan perbaikan mutu pendidikan. Informasi tersebut diperoleh melalui penilaian pendidikan yang valid, kredibel, komparabel, dan dilakukan secara professional dan independen.

Kegiatan penilaian secara umum diharapkan sebagai instrument pemantau dan pengendalian system pendidikan baik ditingkat kelas, sekolah, regional, maupun di tingkat nasional bahkan tingkat internasional. Penilaian seperti ujian akhir nasional dilakukan dalam rangka pengontrolan mutu (quality control) hasil belajar siswa secara nasional di setiap akhir satuan pendidikan atau jenjang pendidikan tertentu. Penilaian kemajuan belajar siswa dilakukan oleh guru dan sekolah melalui kegiatan pemberian tugas, ulangan harian, ulangan akhir catur wulan/ semester, serta ulangan umum kenaikan kelas. Jenis penilaian seperti ini dilakukan dalam rangka pengendalian atau penjaminan mutu (quality assurance) pendidikan. Agar mutu dapat ditingkatkan, maka hasil penilaian tersebut dapat digunakan untuk melakukan perbaikan mutu (quality improvement) pendidikan.

Penilaian hasil belajar siswa di setiap akhir satuan atau jenjang pendidikan dilakukan melalui ujian akhir sekolah dan ujian akhir nasional. Ujian akhir yang dilakukan secara nasional oleh pemerintah menjadi tanggung jawab pemerintah. Karena itu tujuan penilaian hasil belajar secara nasional adalah untuk mengukur sejauhmana pencapaian hasil belajar siswa dan untuk mengetahui mutu pendidikan pada setiap satuan, jenis, atau jenjang/tingkat pendidikan tertentu. Untuk mencapai tujuan tersebut penilaian hasil belajar secara nasional berfungsi sebagi alat pengawasan dan pengendalian mutu pendidikan, bahan pertimbangan dalam penentuan lulusnya siswa, bahan pertimbangan dalam penerimaan siswa ke jenjang pendidikan yang lebih tinggi, dan umpan balik perbaikan program pembelajaran pada setiap tingkat, jenis, satuan, jalur dan jenjang pendidikan. 


\section{PEMBAHASAN}

Terdapat lima prinsip yang harus diperhatikan dalam melaksanakan manajemen kurikulum, yaitu sebagai berikut:

1. Produktivitas, hasil yang akan diperoleh dalam kegiatan kurikulum merupakan aspek yang harus dipertimbangkan dalam manajemen kurikulum. Pertimbangan bagaimana agar peserta didik dapat mencapai hasil belajar sesuai dengan tujuan kurikulum harus menjadi sasaran dalam manajemen kurikulum.

2. Demokratisasi, pelaksanaan manajemen kurikulum harus berasaskan demokrasi yang menempatkan pengelola, pelaksana dan subjek didik pada posisi yang seharusnya dalam melaksanakan tugas dengan penuh tanggung jawab untuk mencapai tujuan kurikulum.

3. Kooperatif, untuk memperoleh hasil yang diharapkan dalam kegiatan manajemen kurikulum perlu adanya kerja sama yang positif dari berbagai pihak yang terlibat.

4. Efektivitas dan efesiensi, rangkaian kegiatan manajemen kurikulum harus mempertimbangkan efektivitas dan efesiensi untuk mencapai tujuan kurikulum sehingga kegiatan manajemen kurikulum tersebut memberikan hasil yang berguna dengan biaya, tenaga, dan waktu yang relatif singkat.

5. Mengarahkan visi, misi dan tujuan yang ditetapkan dalam kurikulum, proses manajemen kurikulum harus dapat memperkuat dan mengarahkan visi, misi, dan tujuan kurikulum (Mulyasa, 2002)

Salah satunya prinsip relevansi, dimana adanya kesesuaian antara komponen tujuan, isi/pengalaman belajar, dan evaluasi kurikulum, serta sesuai dengan kebutuhan masyarakat; (3) pelaksanaan kurikulum dalam meningkatkan mutu pendidikan di SMA Dharmawangsa telah dilaksanakan dengan sangat baik salah satu caranya adalah dengan menggerakkan anggota-anggota kelompok sedemikian rupa hingga mereka berkeinginan dan berusaha untuk mencapai sasaran pendidikan dan sasaran anggota-anggota pihak sekolah tersebut; (4) pengawasan kurikulum dalam meningkatkan mutu pendidikan di SMA Dharmawangsa terlaksana dengan sangat baik, dibuktikan dengan adanya suatu usaha sistematik dalam menetapkan standar pelaksanaan (Suhendri,2019).

\section{SIMPULAN}

Upaya meningkatkan mutu pendidikan di sekolah, satu hal yang perlu di upayakan dan mendapat perhatian besar adalah bagaimana pengelolaan manajemen pendidikan sekolah, dan khususnya adalah manajemen kutikulum. Tanpa adanya perbaikan atau pelaksanaan kurikulum pendidikan yang benar sesuai dengan standar manajemen mutu maka sangat kecil kemungkinan adanya peningkatan mutu di sekolah. Berkaiatan dengan pelaksanaan desentralisasi pendidikan di era otonomi daerah, masing-masing daerah seyogianya memiliki rancangan kurikulum peningkatan mutu tersendiri yang merupakan penjabaran 
atau implementasi dari kurikulum pendidikan yang ditetapkan oleh pusat. Hal demikian sangat sesuai dengan tuntutan kurikulum, dimana baik pemerintah daerah maupun pada level bawah sekalipun (sekolah) diberikan kebebasan untuk menjabarkan program-program peningkatan mutu sehingga dikemudian hari dimasing-masing daerah saling berkompetisi demi kemajuan pendidikan di daerah masing-masing.

\section{DAFTAR PUSTAKA}

Agustiani, D.,S. (2017). Manajemen Kurikulum sebagai Upaya Peningkatan Mutu Lembaga Pendidikan, Thesis, IAIN Tulung Agung.

Conny Semiawan. (2002). Kebijakan Pendidikan Nasional Dasar dan Menengah. Dalam Ikhwanuddin Syarif dan Dodo Murtadlo (ed) Pendidikan Untuk Masyarakat Indonesia Baru; 70 Tahun Prof.Dr.H.A.R Tilaar. Jakarta ; PT. Grasindo

Mulyasa. E, (2002). Manajemen Berbasis Sekolah: Konsep, Strategi dan Implementasi. Bandung; Remaja Rosdakarya

Suhendri. (2019). Penerapan Manajemen Kurikulum dalam Meningkatkan Mutu Pendidikan di SMA Dharmawangsa Medan. Universitas Darmawangsa. Medan

Wahyuni, S.,I. (2009). Manajemen Kurikulum dalam Meningkatkan Mutu Pembelajaran PAI. Skripsi, UIN Yogyakarta. 